\title{
PELATIHAN ETIKA BISNIS DAN PEMBUKUAN BAGI PELAKU UMKM DI SEMOLOWARU KOTA SURABAYA
}

\author{
Nenny Syahrenny ${ }^{1}$, Tegowati ${ }^{2}$, Wininatin Khamimah ${ }^{3}$, In'am Widiarma ${ }^{4}$, Dewi Mutmainnah ${ }^{5}$ \\ ${ }^{1}$ Sekolah Tinggi Ilmu Ekonomi Indonesia (STIESIA) Surabaya, Surabaya, Indonesia \\ 2,3,4,5 Sekolah Tinggi Ilmu Ekonomi Indonesia (STIESIA) Surabaya, Surabaya, Indonesia \\ email: nennysyahrenny@stiesia.ac.id,tegowati@stiesia.ac.id,wininatinkhamimah@stiesia.ac.id
}

\begin{abstract}
ABSTRAK
Usaha Mikro, Kecil dan Menengah (UMKM) di Indonesia menjadi salah satu solusi dalam mengatasi masalah perekonomian. Surabaya yang merupakan salah satu kota terbesar di Indonesia banyak penduduknya yang menjadi pelaku UMKM, dapat dilihat di jalan-jalan besar muncul banyak usaha baik dari makanan, jasa, dan kerajinan. Banyaknya pelaku UMKM ini seperti usaha besar yang mempunyai kelemahan dan kekuatan. Kelemahan utama dari UMKM adalah dalam bidang manajerial. Kurangnya ilmu mengenai manajemen, akuntansi, dan etika dalam berbisnis menyebabkan pelaku UMKM dalam membuat harga tidak sesuai dengan beban penjualannya sehingga tidak dapat bersaing dengan usaha besar. Kelemahan yang ada di UMKM menyebabkan tidak sedikit yang memperoleh keuntungan hanya sedikit sehingga gulung tikar.

Tujuan kegiatan pengabdian ini adalah memberikan pelatihan mengenai penyusunan laporan keuangan yang sesuai dengan Standar Akuntansi Keuangan Entitas Mikro Kecil dan Menengah (SAK EMKM). Dengan menggunakan standar, pemilik akan mendapat petunjuk mengenai penyusunan laporan keuangan, dapat membandingkan kinerja usahanya dari periode sebelumnya dengan periode berjalan. Diharapkan pelaku UMKM dapat memperoleh manfaat dari informasi yang disediakan oleh laporan keuangan. Tujuan selanjutnya adalah memberi motivasi dan semangat kepada pemilik UMKM untuk selalu mengembangkan usahanya, meningkatkan kreativitas dan daya saing melalui perilaku yang beretika.

Metode yang digunakan dalam pelaksanaan pengabdian ini terdiri dari beberapa tahap, yaitu tahap survey, pelaksanaan dan pendampingan. Tahap pertama dilakukan survey pendahuluan ke Kelurahan Semolowaru bersama Kasie Ekonomi Kecamatan Sukolilo membahas mengenai kebutuhan ilmu yang diperlukan pelaku UMKM. Tahap kedua pelaksanaan, tim memberikan materi etika bisnis dengan menggunakan metode ceramah dan tanya jawab. Masalah etika bisnis sering dihadapi pelaku UMKM sehingga dalam pelatihan diharapkan peserta dapat bertukar pikiran untuk mencegah tindakan yang tidak etis. Setelah itu dilaksanakan pelatihan penyusunan laporan keuangan sesuai dengan SAK EMKM. Tahap ketiga adalah pendampingan, peserta diminta untuk menyusun jurnal atas transaksi yang umumnya terjadi di usaha UMKM. Jika ada peserta yang berhasil menyusun laporan keuangan maka akan diberikan doorprize. Pemberian hadiah tersebut menjadi tolak ukur bagi tim pengabdian bahwa materi yang disampaikan telah dapat dipahami, serta untuk menjadi motivasi peserta dalam menyusun laporan keuangan.
\end{abstract}

Kata Kunci: etika bisnis, pembukuan, SAK EMKM, UMKM 


\section{PENDAHULUAN}

Usaha Mikro Kecil dan Menengah (UMKM) selalu menarik untuk dikaji baik di penelitian maupun untuk kegiatan pengabdian. Hal tersebut tidak mengherankan karena sebagian besar masyarakat di Indonesia adalah pelaku UMKM. Data dari Kementrian Koperasi dan UKM tahun 2019 di Indonesia menunjukkan bahwa 99,99\% (65 juta usaha) dari total unit usaha merupakan UMKM. Jumlah usaha yang banyak dapat menyerap tenaga kerja sehingga kontribusi UMKM terhadap perekonomian Indonesia cukup besar.

Surabaya yang merupakan kota terbesar kedua setelah Jakarta, penduduknya juga sebagian besar merupakan pelaku UMKM. Dapat kita lihat banyak pedagang yang menjual baik barang maupun jasa di pinggir jalan maupun di mall. Ruko (rumah toko) banyak berdiri di kota Surabaya untuk dijadikan tempat usaha oleh penduduknya baik makanan, tekstil, kerajinan, agrobisnis dan sebagainya. Contoh di Surabaya tepatnya di Kelurahan Semolowaru Kecamatan Sukolilo Kota Surabaya, pelaku UMKM membentuk komunitas yang dibina oleh pemerintah daerah setempat agar pelaku usaha dapat mengembangkan bisnisnya. Usaha yang ada di Kelurahan Semolowaru Kecamatan Sukolilo Kota Surabaya bermacam-macam, mulai dari usaha makanan, konveksi, jasa, kerajinan tangan (untuk souvenir), batik, dan lain-lain.

Para pelaku UMKM di Kelurahan Semolowaru Kecamatan Sukolilo Kota Surabaya sebagian besar adalah ibu rumah tangga. Mereka membuka usaha dengan tujuan bermacam-macam, ada yang bertujuan untuk membantu perekonomian keluarga, mengembangkan hobi dengan menghasilkan uang, dan ada yang memang fokus untuk mengembangkan bisnisnya. Meskipun pengelolaan manajemen dalam UMKM tidak seperti perusahaan besar, potensi mereka ada dan perlu dikembangkan untuk meminimalkan kelemahan. Seperti yang disebutkan dalam Sarmigi (2020), UMKM mempunyai kekuatan potensial diantaranya adalah memiliki segmen usaha pasar yang unik, melaksanakan manajemen sederhana dan fleksibel terhadap perubahan pasar, memanfaatkan sumber daya alam sekitar dan memanfaatkan limbah, serta memiliki potensi untuk berkembang.

Perkembangan bisnis UMKM sebagian besar masih kurang, hal ini karena beberapa kelemahan didalam UMKM. Permodalan adalah masalah terbesar yang dihadapi pelaku UMKM (Suhery et al., 2020). Kelemahan lainnya yang ada pada UMKM adalah rendahnya pendidikan, kurangnya pemahaman teknologi informasi, kendala penyusunan laporan keuangan, kurangnya kemampuan manajerial, minimnya keterampilan mengorganisir, dan 
terbatasnya pemasaran (Syahrenny, 2019). Pemilik usaha juga kesulitan dalam mengembangkan usahanya karena mereka tidak memiliki informasi yang akurat dan masih mencampur adukkan keuangan rumah tangga dengan bisnisnya (Syahrenny et al., 2021).

Masalah yang dihadapi selain yang disebutkan diatas adalah etika bisnis (Dewi, 2020). Para pemilik masih awam dalam berbisnis, meskipun moral itu juga ada didalam hati nurani masingmasing manusia tidak menutup kemungkinan bahwa manusia dapat berlaku tidak etis karena pengaruh lingkungan. Dengan menerapkan etika dalam berbisnis dapat mempertahankan dan mengembangkan usaha (Khamimah, 2020). Menjalankan kegiatan bisnis, pemilik harus berusaha menghindari efek negatif kepada masyarakat yang ada di sekelilingnya (Gustina, 2008). Hal ini seperti yang disebutkan dalam artikel Khamimah (2020) apabila pemilik usaha melakukan kecurangan seperti mengurangi timbangan atau menjual barang kadaluarsa maka akan dijauhi pembeli. Ketika pembeli tidak ada yang mau datang kembali sudah dipastikan usahanya lama kelamaan akan gulung tikar.

Pelatihan mengenai etika bisnis dan pembukuan kepada UMKM dilakukan oleh Dewi (2020), Khamimah (2020) serta Syahrenny (2019) dan Syahrenny, et al (2021). Dewi (2020) melakukan pelatihan etika bisnis dan pembukuan sederhana, namun tidak disebutkan bahwasanya pembukuan tersebut menggunakan single entry system atau double entry system. Pelatihan dan pendampingan yang dilakukan Khamimah (2020) adalah mengenai etika bisnis saja. Syahrenny (2019) dan Syahrenny, et al (2021) melaksanakan bimbingan teknis di Kabupaten Kediri (2019) dan Bojonegoro (2021). Bimbingan teknis ini diberikan kepada UMKM yang terdaftar pada Dinas Koperasi \& UKM Provinsi Jawa Timur serta Kabupaten Kediri. Bimbingan teknis tersebut hanya membahas cara membuat laporan keuangan sesuai dengan Standar Akuntansi Keuangan Entitas Mikro, Kecil dan Menengah (SAK EMKM). Pengabdian yang dilakukan tim adalah menggabungkan dua pembahasan tersebut yaitu Etika Bisnis dan penyusunan laporan keuangan sesuai dengan SAK EMKM.

Tujuan dari kegiatan pengabdian ini adalah memberi motivasi dan semangat kepada pemilik UMKM untuk selalu mengembangkan usahanya, meningkatkan kreativitas dan daya saing melalui perilaku yang beretika. Tujuan selanjutnya adalah memberikan pelatihan mengenai penyusunan laporan keuangan yang sesuai dengan SAK EMKM. Dengan menggunakan standar, pemilik akan mendapat petunjuk mengenai penyusunan laporan keuangan, dapat membandingkan kinerja usahanya dari periode sebelumnya dengan periode berjalan. Diharapkan pelaku UMKM dapat memperoleh manfaat dari informasi yang disediakan oleh 
laporan keuangan.

\section{Metode}

Metode yang digunakan dalam pelaksanaan pengabdian ini terdiri dari beberapa tahap, yaitu tahap survey, pelaksanaan dan pendampingan. Tahap pertama dilakukan survey pendahuluan ke Kelurahan Semolowaru bersama Kasie Ekonomi Kecamatan Sukolilo. Kemudian tim bersama dengan perwakilan kelompok UMKM membahas mengenai kebutuhan ilmu yang diperlukan pelaku UMKM.

Pelaksanaan dalam tahap kedua kegiatan ini, tim pengabdian memberikan materi etika bisnis dengan menggunakan metode ceramah dan tanya jawab. Peserta pengabdian diminta bertukar pikiran mengenai permasalahan yang dihadapi selama menjalankan bisnis terutama permasalahan etika. Tim pengabdian awalnya menceritakan kasus yang sering terjadi dalam usaha kemudian diberikan etika yang harus diikuti pelaku usaha. Setelah itu dilaksanakan pelatihan penyusunan laporan keuangan sesuai dengan SAK EMKM. Tim pengabdian memberikan dasar-dasar mengenai akuntansi terutama pemahaman mengenai debet dan kredit karena selama ini masyarakat yang tidak memahami akuntansi akan menganggap bahwa debet adalah penerimaan dan kredit adalah pengeluaran. Setelah memahami dasar-dasar tersebut maka berikutnya peserta diberikan pengetahuan mengenai proses akuntansi, mulai dari penyusunan jurnal sampai dengan penyusunan laporan keuangan.

Tahap ketiga adalah pendampingan, tim pengabdian memberikan transaksi yang umum dalam usaha UMKM. Peserta diminta untuk mencatat transaksi tersebut kedalam jurnal dan diposting ke buku besar sampai menjadi laporan keuangan. Tahap ketiga ini sebagai tolak ukur keberhasilan kegiatan pengabdian yang dilakukan tim.

\section{Hasil dan Pembahasan}

Kegiatan pengabdian ini dilakukan pada tahun 2018 sebagai bagian dari kegiatan tridharma perguruan tinggi. Tujuan utamanya adalah membantu masyarakat tertentu dalam beberapa aktivitas, memberikan kontribusi kepada masyarakat khususnya dalam mengembangkan kesejahteraan dan kemajuan masyarakat Indonesia.

Tahap pertama yang dilakukan tim pengabdian adalah melakukan survey pendahuluan ke Kelurahan Semolowaru bersama dengan Kasie Ekonomi Kecamatan Sukolilo Kota Surabaya. Tim pengabdian berdiskusi bersama ketua kelompok UMKM binaan Keluraan Semolowaru untuk mencari solusi atas permasalahan yang dihadapi oleh pelaku UMKM.

Tahap kedua adalah pelaksanaan kegiatan bersama para pelaku UMKM Kelurahan 
Semolowaru. Sebagian besar peserta adalah para ibu dan usaha yang dilakukan kebanyakan adalah usaha makanan/kuliner. Tim pengabdian membekali peserta dengan pemahaman etika bisnis dengan tujuan memberikan semangat dan motivasi kepada pemilik untuk selalu mengembangkan usahanya, meningkatkan kreativitas dan daya saing melalui perilaku yang beretika. Dalam bisnis terutama usaha makanan yang sesuai etika pemilik harus memperhatikan halalnya bahan pokok makanan, kualitas menu makanan, asal-usul dzat makanan, pengelolaan dan penyajian kepada konsumen, menerapkan fresh food, memprioritaskan pelayanan yang baik serta tempat nyaman dan bersih untuk konsumen (Pandhi, 2018). Materi yang diberikan kepada peserta terkait tingkah laku bisnis yang memenuhi syarat dari segi ekonomi, hukum dan moral. Kemudian materi selanjutnya adalah etika didalam bisnis, contoh-contoh perilaku yang etis kepada para stakeholder (terutama konsumen, produsen, kreditur, pemilik, pemerintah dan masyarakat). Selebihnya tim pengabdian dan peserta saling bertukar pikiran mengenai permasalahan yang dihadapi dalam menjalankan usaha. Salah satunya adalah dalam usaha makanan, ketika bahan pokok harga meningkat jangan sampai pelaku UMKM menurunkan kualitasnya dengan menggunakan bahan yang kurang bagus.

Setelah diberikan pengetahuan mengenai etika bisnis, peserta antusias dalam bertanya mengenai permasalahan yang mereka hadapi selama melakukan usaha. Sebelumnya peserta tidak memahami mengenai etika dalam berbisnis karena pemilik belajar berbisnis secara mandiri yang terpenting adalah mendapatkan pendapatan.

Setelah materi etika bisnis selanjutnya tim pengabdian memberikan pelatihan penyusunan laporan keuangan sesuai dengan Standar Akuntansi Keuangan Entitas Mikro Kecil dan Menengah (SAK EMKM). Peserta awalnya sebelum diberikan pelatihan hanya menyusun pemasukan dan pengeluaran berdasarkan kas yang diterima dan kas yang keluar dengan menggunakan buku kas. Informasi yang didapat hanya mengetahui omzet dan uang yang diperoleh. Pelatihan yang diberikan ini memberikan pengetahuan kepada peserta mengenai pemahaman dasar-dasar akuntansi. Dasar-dasar akuntansi ini terutama pemahaman mengenai makna debet dan kredit, akun-akun dalam masing-masing laporan keuangan, bentuk-bentuk baku laporan keuangan serta manfaat laporan keuangan berdasarkan SAK EMKM. Kemudian diberikan penjelasan proses penyusunan laporan keuangan mulai dari jurnal sampai posting ke buku besar dan menjadi laporan keuangan (Gambar 1).

Tahap yang terakhir agar tim mengetahui bahwa kegiatan tersebut sudah dapat diserap dengan baik oleh peserta maka tim memberikan transaksi yang umum ada di UMKM untuk dikerjakan oleh peserta pelatihan. Peserta diberikan kasus transaksi 1 bulan dan diminta untuk melakukan pencatatan, bagi peserta yang dapat menjawab kasus tersebut mendapatkan doorprize. Para peserta sangat antusias dalam mengerjakan kasus yang diberikan dan ada peserta yang berhasil menjawab kasus tersebut (Gambar 2). Penyusunan laporan keuangan yang sesuai dengan SAK EMKM, pemilik akan mendapatkan informasi mengenai aset yang dimiliki, kinerja usahanya dalam 1 periode, dapat membandingkan tiap periode apakah usaha yang dijalankan berjalan stagnan atau berkembang dan dapat mengetahui biaya yang tidak efisien. 


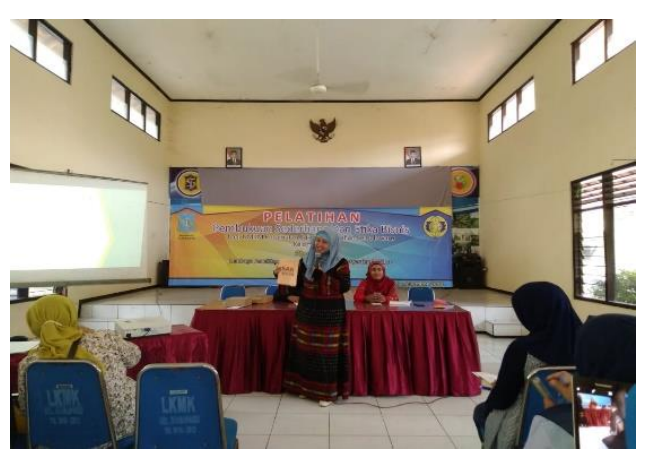

Gambar 1 Penjelasan penyusunan laporan keuangan sesuai SAK EMKM Sumber : Dokumentasi tim pengabdian (2018)

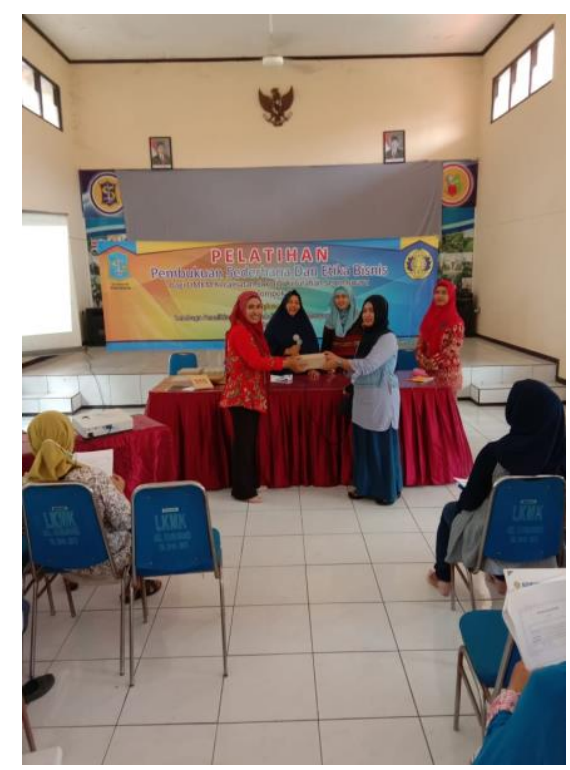

Gambar 2 penyerahan doorprize kepada salah satu peserta yang berhasil menjawab kasus Sumber : Dokumentasi tim pengabdian (2018)

\section{Kesimpulan}

Dalam bisnis harus dilakukan secara etis, salah satunya dalam usaha makanan, pemilik harus memperhatikan halalnya bahan pokok makanan, kualitas menu makanan, asal-usul dzat makanan, pengelolaan dan penyajian kepada konsumen, menerapkan fresh food, memprioritaskan pelayanan yang baik serta tempat nyaman dan bersih untuk konsumen. Peserta setelah mendapatkan pengetahuan mengenai etika bisnis dapat menjalin hubungan 
yang baik dengan konsumen karena dengan berperilaku yang etis mereka mendapatkan kepercayaan dari konsumen sehingga usaha akan berjalan baik (going concern akan lama).

Peserta yang merupakan pelaku UMKM juga mendapatkan pengetahuan mengenai penyusunan laporan keuangan berdasarkan SAK EMKM. Peserta mengetahui manfaat dari penyusunan laporan keuangan yang sesuai dengan standar, diantaranya informasi mengenai aset, kinerja usaha, biaya yang tidak efisien, dan laba yang diperoleh. Transaksi yang diberikan untuk dicatat peserta telah dilakukan dengan baik oleh beberapa peserta dan diberikan doorprize bagi yang berhasil.

Saran untuk kegiatan pengabdian selanjutnya adalah dapat memilih diantara anggota kelompok UMKM tersebut yang telah berhasil dalam menyusun laporan keuangan. Setelah itu dapat disusunkan sistem informasi akuntansi yang memadai agar pencatatan dan dokumentasi bukti lebih tertata rapi.

\section{Ucapan Terima Kasih}

Alhamdulillah segala puji bagi Allah Subhanahu wa Ta'ala serta sholawat dan salam kepada Nabi Muhammad Shallallahu Alaihi Wassalam, atas berkat rahmat dan karunia Allah, tim pengabdian dari Sekolah Tinggi Ilmu Ekonomi Indonesia (STIESIA) Surabaya telah menyelesaikan pengabdian dengan lancar. Penulis mengucapkan terimakasih kepada pihakpihak yang telah mendukung terlaksananya kegiatan pengabdian ini. Pertama, kami ucapkan terimakasih kepada Lurah Semolowaru Kecamatan Sukolilo Kota Surabaya terutama kasie bidang ekonomi yang telah mengijinkan terselenggaranya acara pengabdian. Kedua, kami ucapkan terimakasih kepada Ketua Sekolah Tinggi Ilmu Ekonomi Indonesia (STIESIA) Surabaya yang telah mendukung dan memberikan fasilitas atas kegiatan pengabdian ini. Ketiga, kepada ketua LP2M Sekolah Tinggi Ilmu Ekonomi Indonesia (STIESIA) Surabaya yang telah membimbing dan mengarahkan kegiatan pengabdian tersebut. Ucapan terimakasih pula kepada para peserta dari UMKM di Kelurahan Semolowaru Kecamatan Sukolilo yang antusias sekali dalam mengikuti kegiatan pengabdian yang dilaksanakan oleh tim pengabdian dari Sekolah Tinggi Ilmu Ekonomi Indonesia (STESIA) Surabaya. Terakhir namun tidak berarti tidak penting, yaitu para dosen yang terlibat membantu kegiatan pengabdian ini. Semoga semuanya mendapat pahala jariyah dalam berbagi ilmu bermanfaat.

\section{Referensi}

Dewi, M. A. (2020). Pelatihan Etika Bisnis dan Pembukuan Sederhana Pelaku UMKM di Kelurahan Klampis Ngasem Surabaya. Jurnal Ilmiah Pangabdhi, 6(2), 49-52. https://doi.org/10.21107/pangabdhi.v6i2.7476

Gustina. (2008). Jurnal Etika Bisnis 3.Pdf. 137. 
Khamimah, W. (2020). Pelatihan, Pendampingan Dan Monev Etika Bisnis Saat Pandemi Covid-19 Di Koperasi Toko Kelontong Rungkut Surabaya. Prosiding Seminar Nasional Ke 6 LPPM UPN “Veteran” Yogyakarta, November, 157-164.

Pandhi, R. (2018). Analisis faktor yang mempengaruhi pengembangan usaha untuk peningkatan pendapatan menurut etika bisnis islam. Malia: Jurnal Ekonomi Islam, 10(1), $1-12$.

Suhery, Putra, T., \& Jasmalinda. (2020). Jurnal Inovasi Penelitian. Jurnal Inovasi Penelitian, 1(3), 1-4.

Tegowati, Mutmainnah, Dewi. (2019). Pelatihan Etika Bisnis dan Pemasaran bagi Paguyuban UMKM Semolowaru Surabaya. Seminar Nasional Penelitian Dan Pengabdian Masyarakat, 13-17.

Syahrenny, N. (2019). LAPORAN KEUANGAN UMKM SESUAI SAK EMKM Nenny Syahrenny. Seminar Nasional Penelitian Dan Pengabdian Masyarakat, 13-17.

Syahrenny, N., Kusmaeni, E., \& Qonitah, I. (2021). Bimbingan Teknis Pencatatan Transaksi Keuangan Dalam Meningkatkan Daya Saing UKM Kabupaten Bojonegoro di Era Industri 4.0. Society, 1(2), 93-101. https://doi.org/10.37802/society.v1i2.131

Syahrenny, N., Asyik, N. F., Riharjo, I. B., \& Triyonowati, T. (2021). Pelatihan Manajemen Keuangan Kepada Gapoktan Beras Premium Pojok Kulon Kabupaten Jombang. 1(1). https://ejournal.stiesia.ac.id/kreanova/article/view/4863

Website Kementrian Koperasi dan UKM 